\title{
Studi Literature Essential oil bioactivity of Curry leavess (Murraya koeginii ) as slimming aromatherapy
}

\author{
Rizki Damayanti ${ }^{1.2}$, Harlem Marpaung ${ }^{3 *}$, Zul Alfian $^{3}$, and Tonel Barus ${ }^{3}$ \\ Lecture of FKIP Universitas Serambi Mekkah, Banda Aceh ${ }^{1}$ \\ Student of Department of Chemistry, Universitas Sumatera Utara, Medan, Indonesia ${ }^{2}$ \\ Lecture of Department of Chemistry, Universitas Sumatera Utara, Medan, Indonesia ${ }^{3}$ \\ \{harlem_marpaung@yahoo.com\}
}

\begin{abstract}
Curry leaves is an aromatic plant that contained essential oil. The essential oil mostly has potential as aromatherapy. The aim of this research is to separate the compounds in the essential oil of Kari leaf through fractionation technique and to analyze the potential of the active compound as slimming aromatherapy. The sliming aromatherapy of the obtained each separated essential is evaluated in vivo in male Sprague-Dawley (SD) rats by aromatherapy and inhalation technique. Twenty four rats were used and divided into four groups, namely positive control, negative control, inhale the crude essential oil and inhale the active compound of essential oil. This article contains the research to be done.
\end{abstract}

Keywords: Aromatherapy, Curry, Essential Oil

\section{Introduction}

Curry leaves are aromatherapy plants that have a distinctive odor, so in this study, curry leaves were used as raw material for producing essential oils. Curry leaves essential oil has the potential as an anti-bacterial [1]. Curry leaves contain $0.12 \%$ essential oil [2], and $1.0 \%$ essential oils from dried samples of curry leaves [3].

Types of herbal plant-based aromatherapy slimming drugs are currently being developed. In Indonesia, aromatherapy is nothing new because it has been since ancient times among palace daughters using herbs derived from dried spices which were burned to scent the body. But research on aromatherapy as an inhalation slimming method tends to be very little.

Aromatherapy studies are currently being developed among others by [4] reported that the active compound $\beta$-element in ginger essential oil, red galangal essential oil [5] and grapefruit oil with a limonene dominant content [6] potentially as aromatherapy slimming. The description above shows that the research on slimming aromatherapy with curry leaves essential oil has never been done.

\section{Materials And Methods}

\subsection{Materials}

The materials used include ovens, distillation, chromatographic vessels, capillary pipes, Gas Chromatography-Mass Spectrometry (GC-MS), and enclosures of test animals equipped with inhalator tubes. The ingredients used included curry leaves, aquades, ethyl acetate, chloroform, methanol, n-hexane, silica gel, silica gel G60F254 aluminum plates from Merck, kits (total 
cholesterol, triglycerides, and total cholesterol) BIOLABO Reagent. Laboratory animals of Sprague-Dawley strain adult male rats, standard feed and high cholesterol feed are sourced from egg yolk and Barco ${ }^{\circledR}$ coconut oil.

\subsection{Methods}

This research is conducted in two steps. The initial stage includes the collection of materials, determination of water and ash content, isolation of essential oils using Dean-Stark destilator, fractionation of essential oils using column chromatography and identification of fractions by GC-MS. The next stage is the test of the potential of Curry leavess essential oil and two fractions selected as aromatherapy slimming in vivo to 24 animals tested in adult male Sprague-Dawley strain rats.

\section{Results And Discussion}

Aromatherapy is produced from plants containing essential oils. This study used producer of essential oils. The determination of compounds in essential oils using GC-MS, and potential test as aromatherapy slimming by inhalation method, are used to determine the importance of essential oils, fractionation of essential oils in curry leaves essential oils. This Article contains about research to be done. so in this Article, the results of the research have not been presented. However, the researcher will submit a literature study that the researcher has done as a parameter and preparation for the research to be conducted

\subsection{Curry leaves Sample Preparation}

Curry leaves (Murraya koeginii) belong to the family group Rutaceae (orang-jerukan tribe). Curry leaves are a typical plant in Southeast Asia. Curry plants have a height of 0.9 to 6 meters and a diameter of 15-40 cm. Curry leaves are commonly used as spices in cooking. Curry leaves have a very distinctive aroma and slightly bitter taste, oval shape with a pointed tip. This plant originates from the Indian and Sri Lankan regions and thrives in tropical climates. Curry plants have small yellowish-white flowers, small fruits are green when they are young and purple after they mature. This plant multiplies through seeds and derivatives growing through its roots [7].

Curry plants are classified into the kingdom Plantae, division Spermatophyta, subdivisions of angiosperms, class Dicotyledonae, orde Sapindales, family Rutaceae, genus binomial of Murrayakoenigii (L) S preng [8]. Picture 1. 


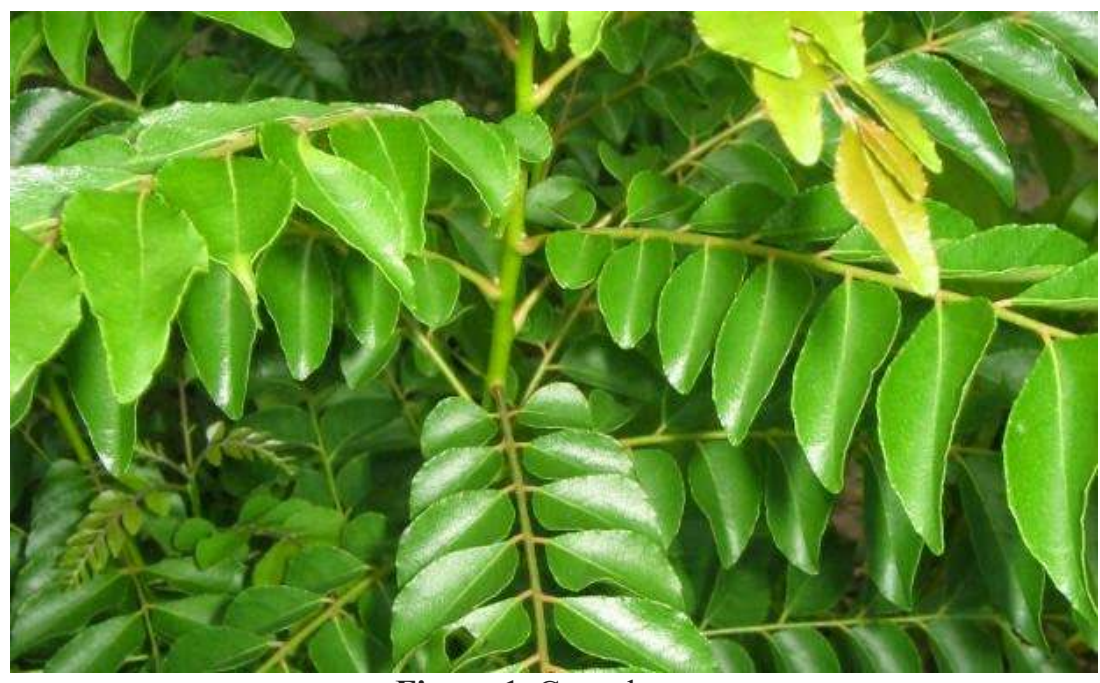

Figure 1. Curry leaves

Water content and sample ash content are determined before distillation. Based on the results of the analysis of curry leaves water content was $54.2 \%$ while the ash content of curry leaves was $5.6 \%$. The purpose of determining water content is to determine the resistance of sample storage. Determination of ash content aims to determine the content of metal minerals in the sample. The maximum ash content limit of herbal plants is 5\% [9]. The results of the experiment to determine the ash content showed that curry leaves samples were suitable for use as medicine.

\subsection{Isolation Essential oils}

Isolation Essential oils can be done by various methods, but tend to be done using steam distillation and water distillation. Nguyen et al.[10] separated the essential oils of fresh curry leaves growing in southern Vietnam using two extraction methods, conventional hydrodistillation and microwave hydrodistillation with $0.83 \%$ and $0.3 \%(\mathrm{w} / \mathrm{w})$ yield respectively. Jamil, Nasir, Ramli, Isha, \& Ismail [11] reported the yield of essential oils of fresh curry leaves using steam distillation and hydrodistillation $0.25 \%$ and $0.09 \%(\mathrm{w} / \mathrm{w})$ respectively

\subsection{Composition of Chemical Compounds in Curry leaves Essential Oils}

Table 1 shows the composition of curry leaves essential oils based on literature studies conducted by researchers. Table 1 shows that the area of origin and treatment of the distillation method of curry leaves samples affect the components of the chemical compounds contained in curry leaves essential oils. The data displayed is characterized using GC-MS. 
Table 1. Composition of Chemical Compounds in Curry leaves Essential Oils.

\begin{tabular}{|c|c|c|c|c|}
\hline & Country & $\begin{array}{l}\text { Composition of } \\
\text { Chemical Compounds }\end{array}$ & Method & Literature \\
\hline 1 & Malaysia & $\begin{array}{l}\text { beta-pelandren } \\
(21.21 \%) \text {, karyophilene } \\
(20.06 \%) \text { beta- } \\
\text { piperdinopropiopenone } \\
\text { (15.71\%), Alpha- } \\
\text { karyophylene }(12.59 \%) \\
\text { and oleic acid }(12.59 \%) \\
\text { karyophilene }(37.98 \%) \text {, } \\
\text { Naphthalene }(16.30 \%) \text {, } \\
\text { Azule }(9.69 \%), \quad 2- \\
\text { hydroxy }(8.46 \%) \text {, and } \\
\text { alpha-pinene }(6.51 \%)\end{array}$ & Hydrodestilation & $\begin{array}{l}\text { Jamil et. all } \\
(2016) \mid\end{array}$ \\
\hline 2 & Vietnam & $\begin{array}{l}\text { Alfa-pinena }(19.03 \%) \text {, } \\
\text { beta-pelandren } \\
(18.22 \%) \\
\text { beta-pinene }(4.03 \%), \\
\text { alpha pinena }(29.81 \%) \\
\text { beta-pelandren } \\
(25.62 \%) \text {, beta-pinene } \\
(6.25 \%)\end{array}$ & $\begin{array}{l}\text { Hydrodestilation } \\
\text { Microwave- } \\
\text { hydrodestilation }\end{array}$ & $\begin{array}{l}\text { Nuyen et.all } \\
(2012)\end{array}$ \\
\hline 3 & Indonesia & 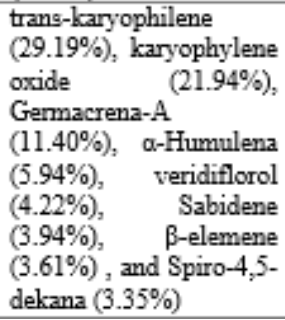 & Steam distillation & Lubis, 2014 \\
\hline
\end{tabular}

\subsection{Potential of Curry Leaves As Aromatherapy Slimming}

The potential of curry leaves as slimming aromatherapy was carried out by in vivo test on test animals Sprague Dawley male rats. Damayanti [5] reported that red galangal essential oil which has the potential as aromatherapy slimming with the main compounds $\beta$-bisabolene $(11.78 \%)$ and Trans- caryophyllene $(9.10 \%)$. Clove essential oil with the main compounds eugenol and $\beta$ - caryophyllene has the potential to be aromatherapy slimming but pure $\beta$ caryophyllene is not potential as aromatherapy slimming. Hasim, Batubara, \& Suparto [12] The main compounds in curry leaves are trans-caryophyllene (29.19\%) and caryophyllene oxide (21.94\%) [1]. The main composition in essential oils of red galangal and curry leaves is transcaryophyllene, so most likely curry leaves essential oils and pure trans-caryophyllene compounds have the potential as aromatherapy slimming.

\section{Conclusion}

This literature study is expected to direct researchers in conducting research on inhalationbased aromatherapy slimming. Furthermore, from the research that will be carried out this is expected to produce an active compound which acts as aromatherapy slimming. 


\section{REFERENCES}

[1] N. Lubis, "Chemical analysis of curry leaves essential oil (murraya koenigii 1.) with GcMs and anti-bacterial activity test. Thesis.," University of Northern Sumatra, 2014.

[2] T. Nagappan, P. Ramasamy, M. E. A. Wahid, T. C. Segaran, and C. S. Vairappan, "Biological activity of carbazole alkaloids and essential oil of murraya koenigii against antibiotic resistant microbes and cancer cell lines," Molecules, no. 16, 2011.

[3] J. U. Chowdhury, M. N. I. Bhuiyan, and M. Yusuf, "Chemical composition of the leaf essential oils of murraya koenigii (L.) spreng and murraya paniculata (L.) Jack," Bangladesh J. Pharmacol., vol. 3, no. 2, pp. 59-63, 2008.

[4] I. Batubara, A. Anggraeni, and L. Darusman, "Inhalation of curcuma scent against rat body weight. J.," Bahan Alam, vol. 8, no. 3, pp. 187-191, 2012.

[5] R. Damayanti, I. Batubara, and I. H. Suparto, "Essential oil of red galangal (Alpinia galanga (L) willd) rhizomes as slimming aromatherapy,” Int. J. Pharma Bio Sci., vol. 6, no. 1, pp. P283-P289, 2015.

[6] J. Shen, A. Niijima, Y. Horii, K. Nagai, M. Tanida, and K. Maeda, "Olfactory stimulation with scent of grapefruit oil affects autonomic nerves, lipolysis and appetite in rats," Neurosci. Lett., vol. 380, no. 3, pp. 289-294, 2005.

[7] Wikipedia, "Salam koja (murraya koenigii syn. chalcas koenigi)," 2012. .

[8] S. V. Jayakumar, S. M. K. Ganesh, A. J. Plant, and S. Res, "The efficacy of aqueous methanolic extract of murraya koenigi (L.) spreng in alloxan induced diabetic albino rats," Pelagia Reserach Libr., vol. 2, no. 3, pp. 263-268, 2012.

[9] S. Dalimarta, Atlas tumbuhan obat indonesia, Jilid 3. 2005.

[10] T. T. T. Nguyen, T. T. Diep, V. Hoang, T. H. M. Vo, F. Duus, and N. Le Thach, "Investigation of curry leaf essential oils of murraya koenigii spreng. Growing in the south of Vietnam," J. Essent. Oil-Bearing Plants, pp. 1021-1029, 2012.

[11] R. Jamil, N. N. Nasir, H. Ramli, R. Isha, and N. A. Ismail, "Extraction of essential oil from murraya Koenigii leaves: Potential study for application as natural-based insect repellent," ARPN J. Eng. Appl. Sci., vol. 11, no. 4, pp. 1-5, 2016.

[12] F. Hasim, I. Batubara, and I. H. Suparto, "The potency of clove (syzygium aromaticum) essential oil as slimming aromatherapy by in vivo assay," Int. J. Pharma Bio Sci., vol. 7, no. 1, pp. 110-116, 2016. 